\title{
Caplet Dosing Unit
}

National Cancer Institute

\section{Source}

National Cancer Institute. Caplet Dosing Unit. NCI Thesaurus. Code C64696.

A dosing unit equal to the amount of active ing redient(s) contained in a caplet. 